\title{
Resistance to Inhibitors of RNA Polymerase in Actinomycetes Which Produce Them
}

\author{
By M. GLORIA BLANCO, CARLOS HARDISSON* AND JOSE A. SALAS \\ Departamento de Microbiologia, Universidad de Oviedo, Oviedo. Spain
}

(Received 22 May 1984 ; revised 28 June 1984)

\begin{abstract}
Resistance to the endogenous antibiotic was studied in three actinomycetes that produce inhibitors of RNA polymerase. The three producers, Nocardia mediterranei (rifamycin producer), Streptomyces spectabilis (streptovaricin producer) and Streptomyces lydicus (streptolydigin producer), were each highly resistant to the antibiotic they produce (MIC $>200 \mu \mathrm{g} \mathrm{ml}^{-1}$ ) and in viwo RNA synthesis was also resistant. However, cross-resistance to the other RNA polymerase inhibitors was not found. Resistance to these antibiotics was due to target site modification, since the RNA polymerase enzymes of the three producing organisms were highly resistant in vitro to the corresponding antibiotic, and no antibiotic-inactivating enzymes were detected. A mutant was isolated from $S$. spectabilis which was sensitive to steptovaricin (its own product) and also showed an increased sensitivity to rifamycin and streptolydigin. This mutant had RNA polymerase which was extremely sensitive to the three antibiotics.
\end{abstract}

\section{INTRODUCTION}

Antibiotic-producing organisms must protect themselves from their own products. In many cases this problem does not really occur, since there is no target site for the antibiotic inside the producing cell; such antibiotics are called xenotoxic (Vining, 1979). In contrast, prokaryotic organisms synthesizing autotoxic antibiotics have to develop specific mechanisms to overcome the toxic effects of their products. Several ways to achieve this have been described. These include modification of the target site (Cundliffe, 1978; Thompson \& Cundliffe, 1980; Cundliffe \& Thompson, 1981 ; Piendl \& Bock, 1982: Thompson et al., 1982; Skinner \& Cundliffe, 1982), inactivation of intracellular antibiotic (Benveniste \& Davies, 1973; Skinner \& Cundliffe, 1980; Hotta et al., 1981; Perez-González et al., 1983) and exclusion of the antibiotic from the cytoplasm (Malik \& Vining, 1972).

There are several antibiotics produced by actinomycetes that inhibit bacterial DNAdependent RNA polymerase. These include the rifamycins, streptovaricins and streptolydigin. Rifamycin (RIF) and streptovaricin (STV), produced by Nocardia mediterranei and Streptomyces spectabilis respectively, seem to act by inhibition of the initiation of transcription (Sippel \& Hartman, 1968; Wehrli et al., 1968), although it has been reported that RIF, at high concentrations, may also inhibit elongation (Kessler \& Hartmann, 1977). On the other hand, streptolydigin (SLG), produced by Streptomyces /ydicus, interferes with RNA chain elongation rather than initiation (Schleif, 1969; Siddhikol et al., 1969; Cassani et al., 1971; Helm et al., 1972), and may lead to premature termination (von Meyenburg et al., 1978).

There has been only one report in the literature concerning resistance to these antibiotics in the producing organisms (Watanabe \& Tanaka, 1976). In that report, RNA polymerase of Streptomyces (now Nocardia) mediterranei (RIF producer) was shown to be resistant to the produced antibiotic when compared with that of Streptomyces griseus (non-producing organism) and

Abbreviations: RIF, rifamycin; SLG, streptolydigin; STV, streptovaricin. 
Escherichia coli. Here, we have extended these investigations to the producers of STV and SLG, and we have also looked for the possible existence of cross-resistance to these three inhibitors at the level of RNA polymerase.

\section{METHODS}

Bacterial strains and culture conditions. Nocardia mediterramei ATCC 13685 was kindly provided by Professor D. A. Hopwood, Department of Genetics, John Innes Institute, Norwich, UK. Streptomyces spectabilis UC-2472 and Streptomyces lydicus UC-2056 were obtained from Dr J. E. Grady, Upjohn Co., Kalamazoo, Mich., USA. These organisms were grown in YEME liquid medium containing the following components $\left(1^{-1}\right)$ : glucose, $10 \mathrm{~g}$; yeast extract, 3 8: malt extract, $3 \mathrm{~g}$; peptone, $5 \mathrm{~g}$. Flasks containing $100 \mathrm{ml}$ YEME liquid medium were inoculated with spore suspensions and incubated for $24 \mathrm{~h}$ at $35^{\circ} \mathrm{C}$ and then $10 \mathrm{ml}$ of such cultures were used as inocula for $500 \mathrm{ml}$ cultures. After growth at $35^{\circ} \mathrm{C}$ for $24 \mathrm{~h}$ in an orbital incubator (Gallenkamp) with shaking, the mycelia were harvested by centrifugation ( 12000 for $15 \mathrm{~min})$, washed twice in buffer $\mathrm{A}\left(50 \mathrm{~mm}-\mathrm{Tr}\right.$ ris/HCl pH 8.4 at $4^{\circ} \mathrm{C}, 10 \mathrm{~mm}$ $\mathrm{MgCl}_{2}, 7 \mathrm{~mm}-2$-mercaptoethanol, I mu-EDTA) and stored at $-20^{\circ} \mathrm{C}$ until use. Micrococcus luteus $\mathrm{ATCC} 10240$ and Bacillus megaterium ATCC 11562 were grown overnight at $35^{\circ} \mathrm{C}$ in Müller-Hinton broth (Difco).

Determination of the minimal inhibitory concentration (MIC). The organisms were inoculated into YEME liquid medium and incubated overnight at $35^{\circ} \mathrm{C}$. YEME solid medium plates containing different antibiotic concentrations were then inoculated using a multipoint inoculator (Steer replicator) and growth on the plates was monitored after $2 \mathrm{~d}$ incubation at $35^{\circ} \mathrm{C}$. Because Streptomyces spp. tend to form clumps in YEME liquid medium, the mycelia were crushed prior to replicating.

Test for antibiotic production. At different times of the growth cycle, samples were centrifuged in Corex tubes $(12000 \mathrm{~g}$ for $15 \mathrm{~min}$ ) and the amount of antibiotic in the supernatant was determined by bioassay. To reduce variations, the supernatant solutions were stored at $-20^{\circ} \mathrm{C}$ until all the samples from the experiment could be assayed together. For the assay, plates of Müller-Hinton medium $(15 \mathrm{ml})$ containing $2 \%(w / v)$ agar were inoculated with $0.1 \mathrm{ml}$ of an overnight culture of $M$. Iuteus (for STV and RIF production) and of $B$. megaterium (for SLG production). The inoculum was spread over the surface of the medium by means of glass beads (2-3 mm diameter). Metal Oxford cylinders containing 50-200 $\mu \mathrm{l}$ of the supernatant were then placed on the top of the medium and the antibiotic allowed to diffuse into the medium for $2 \mathrm{~h}$ at $4^{\circ} \mathrm{C}$. Incubation was then carried out at $35^{\circ} \mathrm{C}$ for $16 \mathrm{~h}$ and the diameters of the haloes were measured and compared with those obtained with known concentrations of STV, RIF and SLG in plates run in parallel.

Isolation of mulants. Mutagenesis of spores was carried out by UV-light treatment. Spore suspensions $(5 \mathrm{ml}$ in $20 \% \mathrm{w} / \mathrm{v}$, glycerol: $\mathrm{OD}_{580}=0.3$ ) were exposed for I min to UV irradiation in an uncovered glass Petri dish. This time was previousiy found to produce about $95 \%$ loss of spore viability. Adequate dilutions were spread over YEME solid medium plates and incubated for $3-4 \mathrm{~d}$ at $35^{\circ} \mathrm{C}$ until the surviving spores formed colonies and sporulated. These were then replica-plated onto YEME solid medium plates containing $100 \mu \mathrm{g}$ antibiotic $\mathrm{ml}^{-1}$. and colonies unable to grow on these plates were selected as possible sensitive mutants. Such colonies were tested again for antibiotic sensitivity after several rounds of colony isolation on solid medium plates without antibiotic. The MICs of these individual colonies were then determined as described above.

Measurements of in vivo RNA synthesis. At different stages of the growth cycle, samples (30 m) were withdrawn. centrifuged and resuspended in a minimal synthetic medium previously described (Hardisson et al., 1980). After preincubation of the cells for 5 min with different concentrations of the antibiotics, the samples were pulselabelled with [ ${ }^{3} \mathrm{H}$ ) uridine $\left(1 \mu \mathrm{Ci} \mathrm{ml} l^{-1}\right.$, specific activity $\left.30 \mathrm{Ci} \mathrm{mmol}^{-1}\right)$ for $5 \mathrm{~min}$ and the reaction stopped by the addition of $1.0 \mathrm{ml}$ ice-cold $10 \%(\mathrm{w} / \mathrm{v})$ trichloroacetic acid (TCA). The tubes were placed in an ice-cold water bath for 30 min before the contents were filtered and washed with $20 \mathrm{ml}$ ice-cold $5 \%$ TCA. The filters were dried and counted in a Beckman LS $100 \mathrm{C}$ liquid scintillation spectrophotometer using a toluene-based scintillation fluid. Corrections were made in all cases for the corresponding blanks.

Partial purification of RNA polymerase. The whole process was carried out at $4^{\circ} \mathrm{C}$. About $10 \mathrm{~g}$ wet weight of mycelium was suspended at $0.2 \mathrm{~g} \mathrm{ml} \mathrm{l}^{-1}$ in buffer $A$ containing $1 \mathrm{~mm}$-phenylmethylsulphonyl fluoride (PMSF) and 1 mM-o-phenanthroline to inhibit proteolytic enzymes. The suspension was then submitted to brief sonication (four $1 \mathrm{~min}$ bursts with intermittent cooling) in an $150 \mathrm{~W}$ ultrasonic disintegrator. This produced disaggregation and partial breakage of the mycelia and was important in order to get maximal yields of the enzyme. Lysozyme (I mg ml-1) was added and the mixture incubated overnight. The extract was treated with polyethyleneglycol (PEG) 6000 and dextran T-500, essentially as described by Babinet (1967), but with minor modifications. A sample of $50 \mathrm{ml}$ extract was mixed with $23.5 \mathrm{ml} 30 \%$ (w/v) PEG 6000 and $8.6 \mathrm{ml} \mathrm{20 \% (w/v)} \mathrm{dextran} \mathrm{T-500,} \mathrm{both} \mathrm{dis-}$ solved in water. After stirring for $30 \mathrm{~min}$, the mixture was centrifuged at $30000 \mathrm{~g}$ for $20 \mathrm{~min}$ and the upper phase discarded. To the lower phase (dextran phase), $18 \mathrm{ml} 30 \% \mathrm{PEG}, 43 \mathrm{ml}$ buffer $\mathrm{A}$ and $20 \mathrm{~g} \mathrm{NaCl}$ were added and the mixture was again stirred for $30 \mathrm{~min}$. After centrifugation at $30000 \mathrm{~g}$ for $20 \mathrm{~min}$, the upper phase (PEG phase) was recovered and dialysed against 21 buffer $A$ which was changed several times. This dialysed extract was submitted to two successive ammonium sulphate precipitations ( $35 \%$ and $70 \%$ saturation) and most of the RNA polymerase 
activity was recovered in the $70 \%$ precipitation. This was dissolved in $4 \mathrm{ml}$ bufier $\mathrm{B}(25 \mathrm{~mm}-\mathrm{Tris} / \mathrm{HCl}, \mathrm{pH} 8.4$ at $4^{\circ} \mathrm{C}, 1 \mathrm{mM}$-EDTA, $7 \mathrm{~mm}$-mercaptoethanol) containing 15\% (v/v) glycerol, $1 \mathrm{mm-PMSF}, 1 \mathrm{mM-o-phenanthroline}$ and $25 \mathrm{~mm}-\mathrm{KCl}$ and again dialysed against the same buffer. The material obtained was applied to a DEAEcellulose column $(10 \times 2 \mathrm{~cm})$, previously equilibrated with buffer $A$ plus $25 \mathrm{mM}-\mathrm{KCl}$ at a flow rate of $30 \mathrm{ml} \mathrm{h}$-1 and washed with $75 \mathrm{ml}$ buffer $B$. Buffer $B(50 \mathrm{ml})$ containing $\mathrm{KCl}(25-400 \mathrm{~mm}$ linear concentration gradient) was applied at a flow rate of $50 \mathrm{ml} \mathrm{h}^{-1}$. Fractions $(2 \mathrm{ml})$ were collected and those containing $R \mathrm{NA}$ polymerase activity pooled, precipitated with $70 \%$ saturated ammonium sulphate and suspended in $2 \mathrm{ml}$ buffer B containing $50 \%$ glycerol and $100 \mathrm{~mm}-\mathrm{KCl}$. These fractions were kept at $-20^{\circ} \mathrm{C}$ until use.

RNA polymerase assays. The assay mixture for determination of RNA polymerase activity contained, in a total volume of $100 \mu \mathrm{l}$, the following components: $50 \mathrm{~mm}-\mathrm{Tris} / \mathrm{HCl} \mathrm{pH} 7.9$ at $25^{\circ} \mathrm{C}, 10 \mathrm{mM}-\mathrm{MgCl}_{2}, 10 \mathrm{mM}-\mathrm{MnCl}_{2}$, $200 \mathrm{~mm}-\mathrm{KCl}, 0.1 \mathrm{~mm}$-dithiothreitol, 0.1 mu-EDTA, $1 \mathrm{~mm}-\mathrm{K}_{2} \mathrm{HPO}_{4}$ pH 7.5, 0.1 mu-GTP, 0.1 mu-CTP, 0.1 muUTP, 0.05 mu- $-2,8,5-{ }^{3} \mathrm{H}$ ]ATP $\left(0.2 \mu \mathrm{Ci} \mathrm{nmol}^{-1}\right), 0.05 \mu \mathrm{g}$ bovine serum albumin, $1 \mu \mathrm{g}$ poly(dA-dT) and 5-50 $\mu \mathrm{l} \mathrm{ex-}$ tract. The reaction was stopped after $15 \mathrm{~min}$ at $37^{\circ} \mathrm{C}$ by the addition of $1 \mathrm{ml} \%$ TCA containing $10 \mathrm{~mm}$-sodium pyrophosphate. After $30 \mathrm{~min}$ at $4^{\circ} \mathrm{C}$, the samples were filtered through Whatman $\mathrm{GF} / \mathrm{C}$ glass fibre discs $(2.5 \mathrm{~cm}$ diameter) and washed with $12 \mathrm{ml} 2 \%$ TCA plus $10 \mathrm{~mm}$-sodium pyrophosphate. The radioactivity in the dried filters was estimated in a Beckman LS $100 \mathrm{C}$ liquid scintillation spectrophotometer. Under these incubation conditions, an incorporation of 40 c.p.m. represented approximately 1 pmol [ ${ }^{3} \mathrm{H}$ ]AMP incorporated into RNA.

Dry weight determinations. Samples were centrifuged, washed twice with double-distilled water and dried at $100^{\circ} \mathrm{C}$ for $24 \mathrm{~h}$ in small glass vials before weighing.

Chemicals and media. Streptovaricin (U-7750, complex) and streptolydigin (U-5481, free acid) were the kind gift of Dr J. E. Grady. Rifamycin SV was from Sigma. The three antibiotics were dissolved in $50 \%(v / v)$ ethanol at $4 \mathrm{mg} \mathrm{ml}^{-1}$. Poly (dA-dT), adenosine $S^{\prime}$-triphosphate, guanosine $S^{\prime}$-triphosphate, cytidine $S^{\prime}$-triphosphate, uridine 5'-triphosphate, malt extract, 2-mercaptoethanol, EDTA, PEG 6000, dextran T-500, lysozyme, DEAE-cellulose (DE-52), peptone, dithiothreitol, phenylmethylsulphonyl fluoride, o-phenanthroline and yeast extract were from Sigma. Ammonium sulphate (enzyme grade) was from Merck. [5. ${ }^{3} \mathrm{H}$ ]Uridine (specific activity $30 \mathrm{Ci} \mathrm{mmol}^{-1}$; $1 \cdot 11 \mathrm{TBq} \mathrm{mmol}^{-1}$ ) was from Amersham and $\left(2,8,5-{ }^{3} \mathrm{H}\right.$ ladenosine $5^{\prime}$-triphosphate (specific activity $46 \mathrm{Ci} \mathrm{mmol}^{-1}$; $1.70 \mathrm{TBq} \mathrm{mmol}^{-1}$ ) was from New England Nuclear.

\section{RESULTS}

\section{Growth, antibiotic production and in vivo resistance}

When inoculated as spore suspensions into YEME liquid medium, $N$. mediterranei, $S$. spectabilis and $S$. lydicus reached the stationary phase of growth after approximately $60 \mathrm{~h}$ incubation at $35^{\circ} \mathrm{C}$. Production of STV and RIF by $S$. spectabilis and $N$. mediterranei, respectively, started very early in the growth cycle (after about $10 \mathrm{~h}$ incubation), while that of SLG by $S$. lydicus occurred after a lag phase of about $38 \mathrm{~h}$ (Fig. 1). The three organisms did not produce very high antibiotic concentrations under our culture conditions but, as will be seen later, the levels of resistance were high. In conventional agar diffusion assays, each of the three organisms was resistant to its own antibiotic product, but cross-resistance to the other antibiotics was not found. Calculations of the MICs (Table 1) confirmed these observations. After UV-light treatment, a mutant of $S$. spectabilis was isolated which was sensitive to STV (MIC $25 \mu \mathrm{g} \mathrm{m}^{-1}$ ) and also showed increased sensitivity to RIF and SLG (MIC $5 \mu \mathrm{g} \mathrm{ml}^{-1}$ for both). This mutant was also examined for its ability to produce STV and was found to produce 12 times less STV than the wild-type strain $(0.03 \mu \mathrm{g} \mathrm{m})^{-1}$ and $0.36 \mu \mathrm{g} \mathrm{ml}^{-1}$ at $100 \mathrm{~h}$ incubation, respectively).

Having established that the three producers were each resistant to their product, the effect of the three antibiotics on RNA synthesis by whole cells was assayed by measuring the incorporation of $\left[{ }^{3} \mathrm{H}\right]$ uridine into TCA-insoluble material. The tendency of Streptomyces to grow as clumps was reduced in these experiments by using a medium consisting of YEME and $34 \%$ sucrose, which promoted diffuse growth (Chater, 1974). Pulse-labelling experiments for each of the three producers showed that in vivo RNA synthesis was not affected by the endogenous antibiotic (Fig. 2). However, cross-resistance to the other antibiotics was found only for $N$.

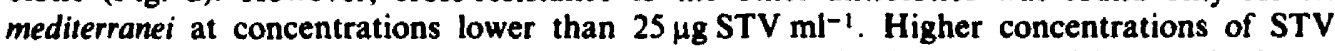
$\left(50 \mu \mathrm{g} \mathrm{ml}^{-1}\right)$ caused inhibition (data not shown). Significantly, there was no difference in the response to the antibiotics when cells in difierent stages of the growth cycle were used, showing that resistance was a permanent property of the cell and was not acquired solely during the phase of antibiotic production. 


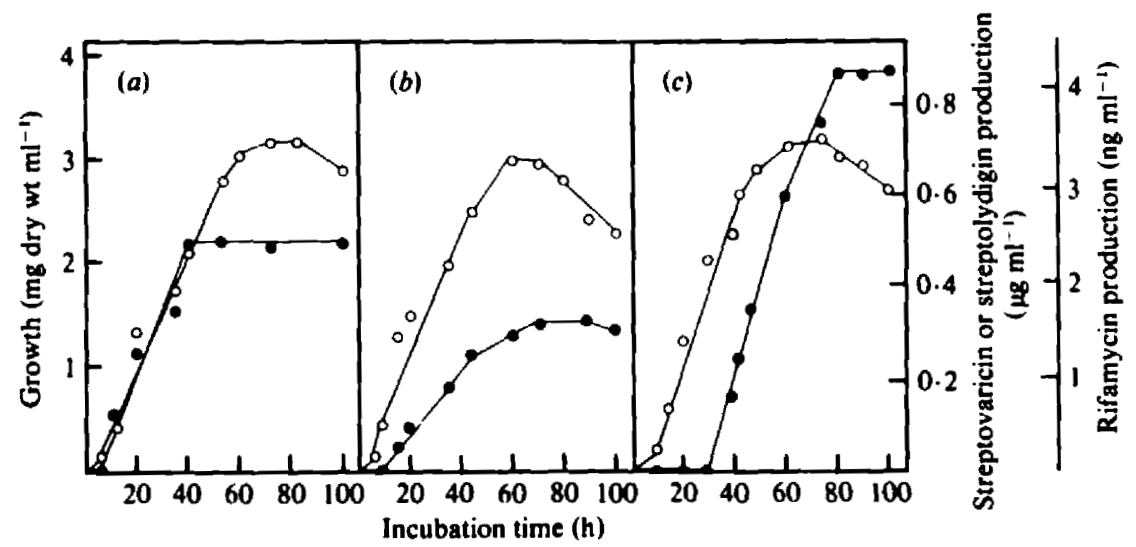

Fig. 1. Growth and antibiotic production by cultures of (a) $N$. mediterranei (rifamycin production). (b) $S$. spectabilis (streptovaricin production), and (c) $S$. Iydicus (streptolydigin production). O, Growth: , antibiotic production. Each value is the average of three determinations.

Table 1. MICs of antibiotic-producer and test organisms

\begin{tabular}{lrcc}
\multicolumn{1}{c}{ Organism } & $\overbrace{\text { Rifamycin }}$ & Streptovaricin & Streptolydigin \\
N. mediterranei & $>200$ & 75 & 25 \\
S. lydicus & 25 & 25 & $>200$ \\
S. spectabilis & 25 & $>200$ & 50 \\
S. spectabilis STV & 5 & 10 & 5 \\
M. Imteus & 1 & 1 & 75 \\
B. megaterium & 5 & 25 & 25
\end{tabular}

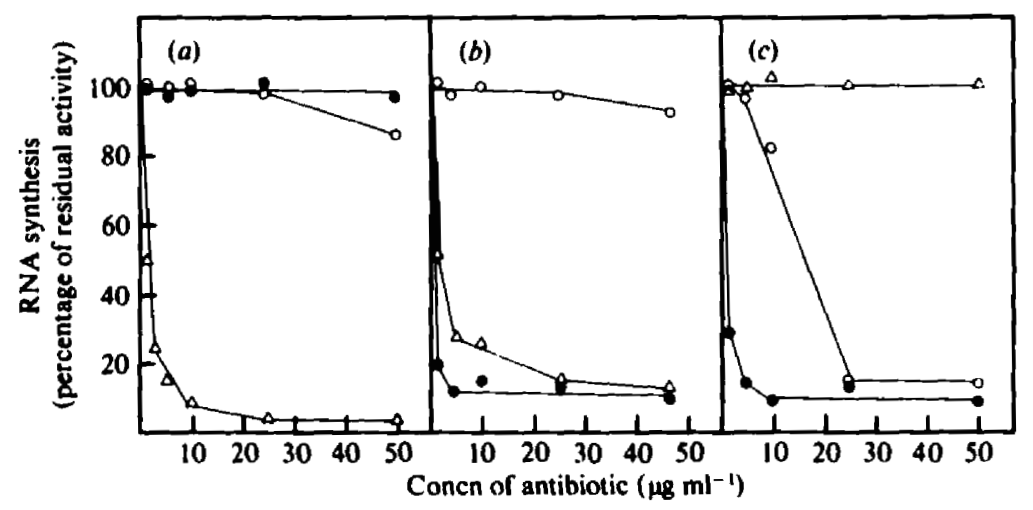

Fig. 2. Effect of rifamycin (O), streptovaricin (O), and streptolydigin ( $\triangle$ ) on RNA synthesis by whole cells of (a) $N$. mediterranei, (b) $S$. spectobilis, and (c) $S$. Iydicus. Cell suspensions (0.5 ml) were incubated with the antibiotic for 5 min before initiating the assay by the addition of ${ }^{3} \mathrm{H}$ )uridine $(1 \mu \mathrm{Ci} \mathrm{m}-1)$. After $5 \mathrm{~min}$ incubation at $35{ }^{\circ} \mathrm{C}$, the reaction was stopped by adding $1 \mathrm{ml}$ ice-cold $10 \%$ TCA. The samples were then processed as described in Methods. 
Table 2. Requirements for RNA polymerase actirity of Streptomyces spectabilis

Similar results were found using enzyme fractions of the other (wo producers (data not shown).

Conditions

Completet

Minus DNA

Minus $\mathrm{MnCl}_{2}$

Minus $\mathrm{MgCl}_{2}$

Minus enzyme

Minus UTP, CTP and GTP

Plus RNAase $\left(5 \mu \mathrm{g} \mathrm{m} \mathrm{m}^{-1}\right)$
Fnzyme activity*

275

25

2

29

18

12

12

- Expressed as pmol [ ${ }^{3} \mathrm{H}$ |AMP incorporated into cold $5^{\circ}$. TCA-insoluble material in $30 \mathrm{~min}$ at $35^{\circ} \mathrm{C}$. All the values are the average of duplicate assays and were in a range $\pm 10^{\circ}$.

+ See Methods for composition of complete assay mixture.

\section{RNA polymerase resistance}

The results described above support the view that RNA synthesis is resistant to the produced antibiotic, but it was possible that the antibiotic was unable to penetrate the cell wall and the cytoplasmic membrane of the producer organism. In order to clarify this point, we tested the sensitivity of the target site of these antibiotics. To do this, we partially purified the RNA polymerase of the three organisms. It was essential to obtain RNA polymerase fractions which were dependent on the addition of exogenous DNA template for the transcription process, since RIF and STV only inhibit the initiation of transcription (Sippel \& Hartmann, 1968; Wehrli et al., 1968) and anomalous results might have been obtained if DNA from Streptomyces or Nocardia were not totally eliminated. This would happen if RNA polymerase could finish transcription of those contaminating DNA fragments in which this process was initiated prior to the addition of antibiotic. Preliminary experiments with crude enzyme preparations from sensitive nonproducing Streptomyces species and very sensitive organisms such as $B$. megaterium and $\boldsymbol{M}$. luteus confirmed this. Contaminating endogenous DNA was removed by partial purification of the enzyme (see Methods) and, in particular, by the use of fractions eluted from DEAE-cellulose columns at $\mathrm{KCl}$ concentrations between 0.2 and $0.3 \mathrm{M}$. These fractions obtained from the producing organism were able to transcribe a wide range of DNA templates (including chromosomal, plasmid and phage DNAs) and also showed high efficiency with a synthetic template, poly(dA-dT) (data not shown). The activities of the three enzymes were dependent on the presence of DNA template, nucleoside triphosphates and both magnesium and manganese ions. As expected, the transcripts were sensitive to RNAase treatment (Table 2). The enzyme was stable for at least 1 month at $-20^{\circ} \mathrm{C}$ in the presence of $50 \%$ glycerol and $1 \mathrm{~mm}$-dithiothreitol.

The sensitivity of these partially purified enzyme preparations to the three antibiotics was tested. The RNA polymerase of each of the three producers was resistant to the produced antibiotic which, in the case of $S$. Iydicus and $S$. spectabilis, even stimulated transcription (Figs 3 and 4). Moreover, in agreement with the results cited above relating to the inhibition of RNA synthesis in viio, the RNA polymerase of each producer was not cross-resistant to the other antibiotics. Only in the case of $N$. mediterranei did the RNA polymerase show a partial resistance to STV. This corresponded with an elevated MIC and the effects upon RNA synthesis in vivo described above. The response of the STV-sensitive mutant of $S$. spectabilis to the three antibiotics was also tested. This mutant was highly sensitive to the three antibiotics (STV, SLG and RIF at $0.1 \mu \mathrm{g} \mathrm{ml} \mathrm{m}^{-1}$ caused about $98 \%, 71 \%$ and $85 \%$ inhibition, respectively; Fig. $4 \mathrm{~b}$ ).

Since the RNA polymerase used was only partially purified, and in order to rule out the possible presence of antibiotic-inactivating enzymes in such preparations, several additional experiments were done. Each individual antibiotic was incubated at $35^{\circ} \mathrm{C}$ for $2 \mathrm{~h}$ with $\mathrm{S} 100$ (supernatant following centrifugation at $100000 \mathrm{~g}$ for $4 \mathrm{~h}$ ) obtained from each producer. This was done in the presence of ATP and acetyl-coenzyme A. Then the residual antibiotic activity of the three antibiotics was tested by two methods: (i) bioassay against $M$. lutetus (for STV and RIF) and against $B$. megaterium (for SLG), and (ii) inhibition of RNA polymerase activity of the STVsensitive mutant. No inactivation of the antibiotics was detected by either method. 


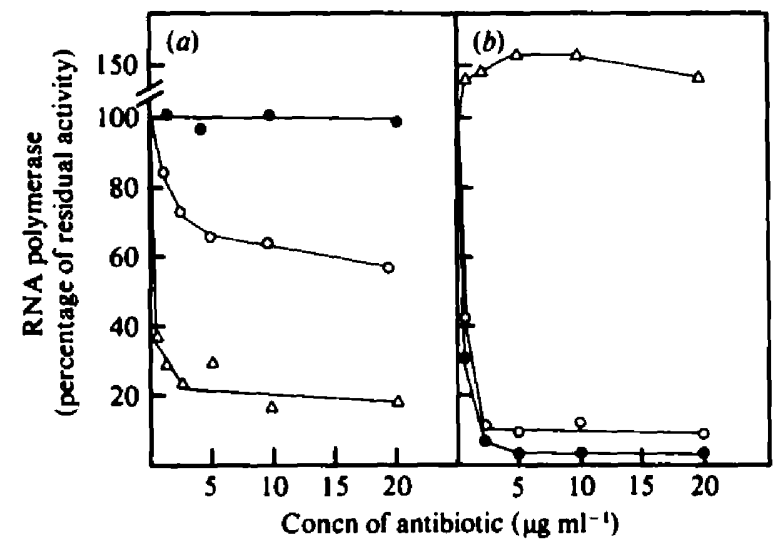

Fig. 3. Effect of rifamycin (O), streptovaricin $(O)$ and streptolydigin $(\triangle)$ on in vitro RNA polymerase activity of $(a) N$. mediterranei and (b) $S$. lydicus. The enzyme fractions were incubated for 5 min with antibiotic before initiating the reaction. After $15 \mathrm{~min}$ at $37^{\circ} \mathrm{C}$, the reaction was stopped with $1 \mathrm{ml}$ ice-cold TCA containing 10 mm-sodium pyrophosphate and the radioactivity incorporated into TCAinsoluble material determined after processing of the samples, as described in Methods.

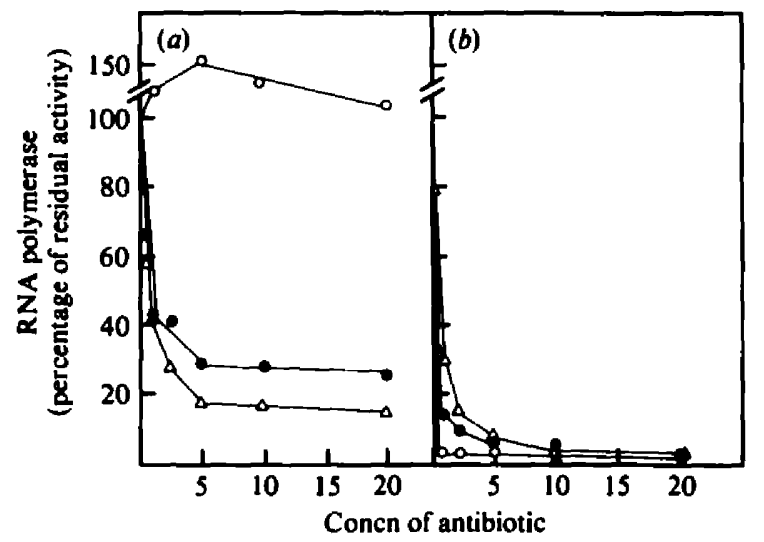

Fig. 4. Effect of rifamycin (O), streptovaricin $(O)$ and streptolydigin $(\triangle)$ on in vitro RNA polymerase activity of wild-type $(a)$ and a streptovaricin-sensitive mutant $(b)$ of $S$. spectabilis. Conditions were the same as those described for Fig. 4.

\section{DISCUSSION}

The study of antibiotic-resistance mechanisms in actinomycetes has become a very attractive field of research, particularly since the suggestion that the resistance determinants found in clinical isolates could have an origin in the producing organisms (Walker \& Walker, 1970; Benveniste \& Davies, 1973). Evidence supporting this hypothesis has appeared in recent reports showing sequence homology between antibiotic-resistance genes from producing bacteria and from transposon-located genes (Herbert et al., 1983; Thompson \& Gray, 1983). However, most of the work on these resistance mechanisms has been done with antibiotics acting on protein synthesis, and only a few reports have been published on inhibitors of RNA polymerase. Mutants resistant to inhibitors of RNA polymerase have been isolated from non-producing organisms and have been shown to have RNA polymerase resistant to the drug (Schleif, 1969; Yura \& Igarashi, 1968; Iwakura et al., 1973; Sonenshein et al., 1974; Halling et al., 1978). This 
was also the case for RIF resistance in N. mediterranei (Watanabe \& Tanaka, 1976). Most of these resistant mutants showed cross-resistance between RIF and STV (Yura \& Igarashi, 1968) but cross-resistance between these two antibiotics and SLG was not always found (Iwakura et al., 1973; Sonenshein et al., 1974). We report here that the actinomycetes producing RIF, STV and SLG are resistant to their own antibiotics due to target site modification. Resistance seems to be constitutively expressed and was observed throughout the cell cycle, independent of the period of antibiotic production. In addition, we could separate resistance to RIF and STV completely in $S$. spectabilis (STV producer) and partially in $N$. mediterranei (RIF producer), suggesting that the modifications of RNA polymerase responsible for resistance in these organisms are different. Additional support for the view that resistance is associated with the alteration of RNA polymerase comes from a mutant of $S$. spectabilis selected as STV-sensitive and which also has RNA polymerase sensitive to STV. In this strain, the mutation for STV sensitivity increased the affinity of the RNA polymerase for both STV and RIF. This suggests that, although the resistance mechanisms in the respective producers may not be exactly the same, there must be a relation between them. This mutant showed another feature. The acquisition of the STV-sensitive phenotype was accompanied by a great decrease in antibiotic production. The importance of this is clear if one considers the necessity for an antibioticsensitive organism to be a non-producer (or low-level producer) in order to avoid 'suicide'. It is possible that this mutant is the result of a unique lesion in structural gene of the RNA polymerase yielding an antibiotic-sensitive product which, in some way, regulates the expression of the genes for antibiotic synthesis. Alternatively, this mutant could be the result of a double mutation (one in a structural gene for RNA polymerase and another in an antibiotic production gene), but the statistical probability of this occurring is very low.

Another interesting point arising from our study was the fact that antibiotics produced by $S$. lydicus (SLG) and S. spectabilis (STV) not only failed to inhibit the RNA polymerase of the producer but even enhanced its activity. This phenomenon was observed previously in a streptolydigin-resistant mutant of Bacillus subtilis (Halling et al., 1978). It is possible that the interaction of the antibiotic with the modified subunit of the enzyme induced some conformational changes in the multimeric protein structure making the binding of RNA polymerase to the DNA template more effective. It is interesting in this context that RIF-dependent mutants have been reported in $E$. coli (Dabbs, 1979).

Resistance to inhibitors of RNA polymerase in non-producer organisms has been reported to be associated with the $\beta$ subunit (Rabussay \& Zillig, 1969; Boyd et al., 1974; Linn et al., 1975; Halling et al., 1977, 1978; Boothroyd et al., 1983). In some cases, the modification alters the electrophoretic mobility of the subunit (Linn et al., 1975) and it has recently been shown that rifampicin resistance mutations in $E$. coli were due to a change in only one amino acid in the $\beta$ subunit sequence (Ovchinnikov et al., 1983). Work in progress in our laboratory is focused on the elucidation of the modification in the RNA polymerase subunit responsible for resistance in the producer organisms.

We wish to thank Dr Eric Cundliffe for encouraging us in the realization of this project and for critical reading of the manuscript, and Dr F. Parra for helpful suggestions in the RNA polymerase purification. We also thank Professor D. A. Hopwood for the kind gift of Nocardia mediterranei and Upjohn Co. for the kind gift of streptovaricin, streptolydigin and both producer organisms.

M. G. B. was the recipient of a predoctoral fellowship of the Ministry of Education and Science, Spain. This work was supported in part by a grant of the Comisión Asesora para el desarrollo de la Investigación CientificoTécnica, Spain.

\section{REFERENCES}

BABINET, C. (1967). A new method for the purification of RNA polymerase. Biochemical and Biophysical Research Communications 26, 639-644.

Benveniste, R. \& Davies, J. (1973). Aminoglycosideantibiotic inactivating enzymes in actinomycetes similar to those present in clinical isolates of antibiotic-resistant bacteria. Proceedings of the National
Academy of Sciences of the United States of America 70, 2276-2280.

Boothroyd, C. M., Malet, R. M., Nene, V. \& Glass, R. E. (1983). Genetic studies on the $\beta$ subunit of Escherichia coli RNA polymerase. III. Analysis of low level rifampicin-resistant mutants. Molecular and General Genetics 190, 523-526. 
BOyd, D. H., Zillig, W. \& SCAIFE, F. J. G. (1974). Reference mutations for the $\beta$ subunit of RNA polymerase. Molecular and General Genetics 130. 315-320.

Cassan, G., Burgess, R. R., Goodman, H. M. \& GoLD, L. (1971). Inhibition of RNA polymerase by streptolydigin. Nature New Biology 230, 197-200.

ChateR, K. F. (1974). Rifampicin-resistant mutants of Streptomyces coelicolor A3(2). Journal of General Microbiology 80, 277-290.

CUNDLIFFE, E. (1978). Mechanism of resistance to thiostrepton in the producing-organism Streptomyces azureus. Nature, London 272, 792-795.

CUNDLIFFe, E. \& ThOMPSON, J. (1981). The mode of action of nosiheptide (multhiomycin) and the mechanism of resistance in the producing organism. Journal of General Microbiology 126, 185-192.

DABBs, E. R. (1979). New tool for studying interactions of components of ribonucleic acid polymerase: rifampin-dependent mutants. Journal of Bacteriology 139. 1072-1074.

Halling, S. M., Burtis, K. C. \& Dol, R. H. (1977). Reconstitution studies show that rifampicin resistance is determined by the largest polypeptide of Bacillus subtilis RNA polymerase. Joumal of Biological Chemistry 252, 9024-9031.

Halting, S. M., Burtis, K. C. \& Doi, R. H. (1978), B subunit of bacterial RNA polymerase is responsibie for streptolydigin resistance in Bacillus subtilis. Nalure, London 272, 837-839.

Hardisson, C., Salas, J. A., Guijarro, J. A. \& SuÁrez, J. E. (1980). Macromolecular synthesis during the germination of Streptomyces spores in a chemically defined medium. FEMS Microbiology Letters 7, 233-235.

HeLM, K. VON DER. \& Krakow, J. S. (1972). Inhibition of RNA polymerase by streptolydigin. Nature New Biology 235, 82-83.

Hekbert, C. J., Giles, I. G. \& AkrtaR, M. (1983). The sequence of an antibiotic resistance gene from an antibiotic-producing bacterium: homologies with transposon genes. FEBS Letters 160, 67-71.

Hotta, K., Yaunuoto, H., Oxami, Y. \& Umezawa, H. (1981). Resistance mechanisms of kanamycin-, neomycin-, and streptomycin-producing streptomycetes to aminoglycoside antibiotics. Journal of Antibiotics 34, 1175-1182.

IWAKURA, Y., IshthaMA, A \&URA, T. (1973). RNA polymerase mutants of Escherichia coli. Il. Streptolydigin resistance and its relation to rifampicin resistance. Molecular and General Genetics 121, 181. 196.

Kessler, C. \& Hartmann, G. R. (1977). The two effects of rifampicin on the RNA polymerase reaction. Biochemical and Biophysical Research Communications 74, 50-56.

LinN, T., Losicx, R. \& Sonenshein, A. L. (1975). Rifampicin resistance mutation of Bacillus subrilis altering the electrophoretic mobility of the $\beta$ subunit of ribonucleic acid polymerase. Journal of Bacteriology 122, 1387-1390.

MaLIK. V.S \& VINING, L. C. (1972). Chloramphenicol resistance in a chloramphenicol-producing Streptomyces. Canadian Journal of Microbiology 18, 583-590.

Meyendurg, K von, Nielsen, L. D., Johnsen, K., Moli, S., Svenningsen, B. \& Mozzari, G. (1978).
Reevaluation of the mode of action of streptolydigin in Escherichia coli: induction of transcription termination in view. Antimicrobial Agents and Chemotherapy 13, 234-243.

Ovchinnikov, Y. A., Monastyrsicaya, G. S., Gurier, S. O., Kalinina, N. F., Sverdlow, E. D., Gragerov, A. I., Bass, I. A., Kiver, I. F., Molseyeva, E. P., Igumnov, V. N., Mindlin, S. Z., Nikiforov, V. G. Khesin, R. B. (1983). RNA polymerase rifampicin resistance mutations in Escherichia coli: sequence changes and dominance. Molecular and General Genetics 190, 344-348.

Pérez-Gonzílez, J. A., Vara, J. \& Jiménez, A. (1983). Acctylation of puromycin by Streptomyces alboniger the producing organism. Biochemical and Biophysical Research Communications 113, 772-777.

PIENDL, W. \& Bocx, A. (1982). Ribosomal resistance in the gentamicin producer organism Micromonospora purpurea. Antimicrobial Agents and Chemo. therapy' 22, $231-236$.

Rabussay, D. \& Zillig, W. (1969). A rifampicin resistant RNA polymerase from Escherichia coli altered in the $\beta$ subunit. FEBS Letters 5, 104-106.

SCHLEIF, R. (1969). Isolation and characterization of a streptolydigin resistant RNA polymerase. Nature New Biology 223, $1068-1069$.

Siddhixol, C., Erastoezer, J. W. \& Weisblum, B (1969). Mode of action of streptolydigin. Joumal of Bacteriology 99, 151-155.

Sippel, A. \& Hartmann, G. R. (1968). Mode of action of rifamycin on the RNA polymerase reaction. Biochimica et biophysica acta 157, 218-219.

SKINNER, R. H. \& CUNDLIFFE, E. (1980). Resistance to the antibiotics viomycin and capreomycin in the Streptomyces species which produce them. Journal of General Microbiology 120, 95-104.

SxinNeR, R. H. CUNDLIPfE, E. (1982). Dimethylation of adenine and the resistance of Streptomyces erythreus to erythromycin. Journal of General Microbiology 128, 2411-2416.

Sonenshein, A. L., Cami, B., Brevet, J. \& Cote, R. (1974). Isolation and characterization of rifampicinresistant and streptolydigin-resistant mutants of Bacillus subtilis with altered sporulation properties. Journal of Bacteriology 120, 253-265.

Thompson, J. \& CUNDLIFFe, E. (1980). Resistance to thiostrepton, siomycin and sporangiomycin in actinomycetes that produce them. Joumal of Bacteriology 142, 455-461.

Thompson, C. J. \& Gray, J. (1983). Nucleotide sequence of a streptomycete aminoglycoside phosphotransferase gene and its relationship to phosphotransferases encoded by resistance plasmids. Proceedings of the National Academy of Sciences of the United States of America 80, 5190-5194.

Thompson, J., CundlifFe, E. \& STARK, M. (1982). On the mode of action of berninamycin and the mechanism of resistance in the producing organism. Streptomyces bernensis. Journal of General Microbiology 128, 875884.

VINING, L. C. (1979). Antibiotic tolerance in producer organisms. Advances in Applied Microbiology 25, 147 168.

W ALKER, M. S. \& WALKER. J. B. (1970). Streptomycin biosynthesis and metabolism. Journal of Biological Chemistry 245, 6683-6689. 
Watanabe, S. \& Tanaka, K. (1976). The effect of rifampicin on in vitro RNA synthesis of Streptomyces mediterranei. Biochemical and Biophysical Research Communications 72, 522-529.

WehRl, W., KNUSEl. F. SCHMid, K. \& StaEhelin, M (1968). Interaction of rifamycin with bacterial RNA polymerases. Proceedings of the National Academy' of
Sciences of the United States of America 61, 667673.

YURA, T. \& IGaRAshi, K. (1968). RNA polymerase mutants of Escherichia coli. I. Mutants resistant to streptovaricin. Proceedings of the National Academy of Sciences of the United States of America 61. 13131319. 